\title{
1. The bottom-up power of informal entrepreneurship
}

\section{José Ernesto Amorós, Juan Pablo Couyoumdjian, Oscar Cristi and Maria Minniti}

\section{INTRODUCTION}

Interest in the informal sector has a long history in economics (see Gerxhani, 2004 and Schneider and Enste, 2000 for a review of the literature), and is now receiving increasing attention in management (Bruton et al., 2008; Bowen and De Clercq, 2008; and Godfrey, 2012) and in entrepreneurship research (see the special issue of Strategic Entrepreneurship Journal, 2014).

Traditionally, the informal sector is perceived as an inefficient and potentially negative side of the economy since its operations tend to be characterized by low productivity. Informal activities are also viewed as having negative social dimensions. For example, since workers in the informal sector usually lack the protection of safety nets existing in the formal labor market, they are considered to be exposed to the risk of exploitation. In addition, informality is perceived as producing unfair competition for formal companies, as well as imposing a burden on national finances since it allows for the avoidance of taxes (Schneider and Enste, 2000). Considerations about the opportunity costs of the informal sector are particularly significant when taking into account that, while an informal sector exists in virtually every country, in some of them it accounts for more than half of total GDP (Schneider et al., 2010; ILO, 2011).

Yet De Soto (1989) suggested that the informal sector plays an important role in economic development and that such a role goes beyond its contribution to GDP per capita (Sen, 1999; Misturelli and Heffernan, 2008) and that, in fact, GDP alone does not capture the real contribution potentially provided by informal activity. Within this context, Gries and Naudé (2011), Gollin (2008), Maloney (2004) and Shane (2009) all have noted the relationship between informal activities and entrepreneurial activities and pointed out that much of the legal activity in the informal 
sector takes the form of small ventures. Although there is no denying the efficiency price associated with informal economic activity in an environment characterized by efficient institutions, we argue that, in an environment with weak institutions and, therefore, high costs of doing business, participation in the informal sector may be linked to measurable positive outcomes as suggested by De Soto.

Specifically, we claim that informal economic activity is inherently entrepreneurial. As a result, contrary to standard arguments stating that development is negatively correlated to the size of the informal sector, we suggest that, under certain conditions, the informal sector allows for the exploitation of otherwise idled opportunities. In addition, we argue that the informal sector is an important vehicle for economic activity with a positive and important effect on human development even though such an effect may not be reflected in changes in per capita GDP. For example, a significant portion of female employment in developing countries consists of micro-entrepreneurial activity in the informal sector. While at the aggregate level this activity does not have a measurable impact on per capita GDP, it does generate improvements in living standards and allows women to circumvent cultural and institutional barriers.

We use country-level data to support our argument. Specifically, using data from the Global Entrepreneurship Monitor (GEM) project, the International Labour Organization (ILO), the Shadow Economic Index, and the United Nations Human Development Index (HDI), we investigate the existence of a positive relationship between the size of the informal economy and human development. Our results provide evidence that the informal sector has in fact a positive effect on development and that, in countries with weak institutions, it provides a viable substitute for activity in the formal sector and is associated with positive changes in human development. In other words, our results show that, in the presence of incongruent institutions, a certain amount of informal activity is desirable not only at the individual level, but at the aggregate level as well. Our results are robust across several model specifications.

We contribute to the literature investigating the role that informality plays in the economy in three important ways. First, we highlight the entrepreneurial dimensions of legal informal activity. Second, we reevaluate the role of the informal sector in the process of development, a relationship that had been previously addressed only indirectly, and show that the effect may be positive and desirable, especially in developing countries. Thus, our work complements De Soto (1989), who argues in favor of living with informality. Second, our results provide some preliminary evidence on the size of the positive effect that the informal sector has on economic development. Within this context, we show that much of the 
impact of informal entrepreneurship is mediated by the effectiveness of a country's institutional context. Thus, our work complements Baumol's (1990) seminal work on the role institutions play on the distribution of entrepreneurial activity across alternative types, and Webb et al.'s (2009) analysis of the relationship between informal activity and the existence of incongruent institutions.

The next section presents our theoretical framework. The second section describes the data and variables used in the chapter. We then show our estimation strategies and results. Finally, the last section concludes and briefly discusses the limitations and implications of our work.

\section{LITERATURE REVIEW AND THEORY DEVELOPMENT}

Webb et al. (2009) define the informal economy as the set of illegal yet legitimate activities through which individuals exploit opportunities. Consistently, a generally agreed upon definition for the informal sector (or shadow economy) is that it describes the use of illegal means to pursue legal activities that have a positive economic value (Schneider and Enste, 2000). The extant literature has also shown convincingly that a significant portion of entrepreneurial activity takes place in the informal sector which is, in fact, constituted primarily by smaller subsistence-oriented ventures (Webb et al., 2013).

Recent studies have examined empirically the determinants of informality and found that the size of the informal sector in an economy depends on the extent of tax-burdens, labor market regulations, the quality of government institutions, and financial credit constraints (Loayza, 1996; Loayza et al., 2005; Schneider and Enste, 2000). Importantly, the effects of a higher tax burden on informality have been shown to depend not only on the tax rates, but also on how the tax system is administered (Johnson et al., 1998). Similarly, regulatory burden and uncertainty, and their impact on corruption and weak respect for the rule of law, have been linked to the size of the informal sector (Johnson et al., 1998; Anokhin and Schulze, 2009). These effects are also consistent with evidence on the regulation of entry (Djankov et al., 2002).

Clearly, institutions play a crucial role in determining individuals' choices regarding whether to operate in the formal or informal sector (Dell'Anno, 2010), a role that has been shown to be quite robust across countries and alternative political systems (De Soto, 1989; Friedman et al., 2000). These findings are consistent with and complement our extant understanding that institutions influence the distribution of entrepreneurial activity 
across alternative types of entrepreneurship (Baumol, 1990; Boettke and Coyne, 2007). Good institutions lead to an efficient allocation of resources and generate the correct incentives for innovation and productive entrepreneurship (Baumol et al., 2007; Baumol, 1990). Furthermore, in a recent fine-grained qualitative study, De Castro et al. (2014) have highlighted the mediating role institutions play between entrepreneurs and their environment.

As Webb et al. (2009) put it, informal activity emerges when individual and public incentives are misaligned. That is, a gap exists between activity sanctioned as being legal and activity perceived as being legitimate by sufficiently large groups. ${ }^{1}$ Thus, doing business in the informal sector may be considered as the individual's legitimate response to the relative incentives created by an environment where weak institutions limit, whether by imposing constraints or by increasing costs, one's ability to start a business in the formal sector of the economy. Since economic decision-making always takes place in the context of scarce resources, the desirability of informal activity stems from the fact that it constitutes an individual's best response to the specific environment she or he is facing (Yamada, 1996).

Taken together, the evidence provided by this literature shows that institutions matter for the emergence of informal activity because they guide the allocation of resources in the economy (Easterly, 2002; North, 1990). Thus, in a world with good institutions the advantages for engaging in the informal sector are limited and informality will primarily have the negative effect predicted by much of the literature. For example, informal firms would not be able to realize the advantages of well-defined property rights or expand their activities to the extent allowed by a free market (De Soto, 2000). On the other hand, in countries characterized by incongruent institutions, undertaking activities informally may be a rational and well-being enhancing choice.

Of course, individuals' best responses do not necessarily produce desirable results at the aggregate level. Research focusing on the macroeconomic role played by the informal economy has focused primarily on three groups of issues related to this point. First, issues related to the size and scope of the regulations that influence the distribution of activity between the formal and the informal sectors (Yamada, 1996). Second, micro-level issues associated with social concerns and with the impact the informal sector has on poverty and lack of opportunities (Tokman, 2007; Banerjee and Duflo, 2007). Third, issues related to the contribution, if any, to productivity and the value generated by activities in the informal sector (Maloney, 2004). We are interested in the aggregate effects of the informal economy on human development. Thus, our chapter fits primarily in the third group.

The amount of research aimed at assessing the aggregate impact of the 
informal sector on development is relatively limited. More importantly, the empirical literature provides conflicting results. Loayza (1996) found the effect of informality on economic growth to be negative. Easterly (2002) showed growth to be negatively related to informal production. Similarly, LaPorta and Shleifer (2008) found evidence that the size of the informal economy has a strong negative correlation with per capita income and that firms established in the formal sector are the main sources of productivity in the economy. These findings are consistent with the view that informality is primarily a transitory and involuntary alternative to formal activity. As Tokman (2007) points out, this survivalist view of informality implies an overall fragility and vulnerability of the informal sector and underlies its undesirable character.

In contrast, Maloney (2004) found evidence that most economic agents decide to work in the informal sector voluntarily and, as a result, argued that informality has an important voluntary component. Similarly, in a comprehensive study of Latin America undertaken by the IBRD and the World Bank, Perry et al. (2007) argued that the majority of informal activity is voluntary and that most workers attach significant value to nonpecuniary benefits and choose deliberately to exit formal social protection systems. Amorós and Cristi (2011) also found similar results, even in the context of necessity-motivated entrepreneurship in Latin America.

Overall, the heterogeneity of motives for engaging in informal activities cautions against simple generalizations. While exclusion from formal employment explains the undertaking of activities in the informal sector for some individuals, the documented voluntary nature of much informality suggests that the latter satisfies needs that may not necessarily be reflected in income changes. For example, owning a business, albeit a small and informal one, may signal leadership ability and status in a community, or increase empowerment and self-reliance. Also, for people with low educational attainments, self-employment may provide more upward mobility than the formal sector, or supplemental sources of income. These are just a few of the many economic and non-economic factors that may motivate individuals to choose informality voluntarily.

If one embraces the entrepreneurial and voluntary nature of much informal activity, informality does not emerge necessarily as a weak and negative aspect of business life but, rather, as an effective coping strategy to external constraints, even though its positive effects may not be measurable in changes in per capita GDP. According to this view, informality is the manifestation of a dynamic entrepreneurial spirit in an economy. This is consistent with the observation that some level of informal activity emerges even in economies characterized by well-functioning institutions. Similarly, the bottom-up nature of informal entrepreneurship is at the core 
of De Soto's 1989 seminal work. For example, De Soto described the state of affairs in the public transport industry in Lima, Peru, where, at the time he was writing, more than half of the industry was part of the shadow economy. These transportation services emerged as small entrepreneurial ventures and operated informally in response to the excessive burden of regulations imposed on the industry. These informal entrepreneurial activities, De Soto contends, provided a significant contribution to Lima's development.

To summarize, in a world with efficient institutions we would expect to see only a limited informal sector. On the other hand, in a world with inefficient institutions, activity in the informal sector is the entrepreneurial response to institutional constraints and allows for the mobilization of resources that, otherwise, these constraints would leave unused or underused. Given the entrepreneurial nature characterizing the activities taking place in it, we hypothesize that the informal sector, and its entrepreneurial component in particular, have a positive aggregate effect on human development and that, as a result, a certain amount of informal activity may be desirable. We also hypothesize the strength of this effect to be associated to the quality of formal institutions.

\section{DATA AND VARIABLES}

To measure a country's level of economic development we use two alternative variables. First, we use the Human Development Index (HDI) calculated by the United Nations Development Program and published in the Human Development Reports. ${ }^{2}$ The HDI is a composite index that measures average achievement in a country by considering three dimensions of human development: life expectancy at birth (long and healthy life); adult literacy rate (education and knowledge); and GDP per capita in purchasing power parities. Since its three dimensions reflect the major themes and topics associated with poverty (Misturelli and Heffernan, 2008), the HDI is broadly accepted as a proxy for economic development. The HDI is calculated as the geometric mean of normalized indices for life expectancy, education and income per capita, and takes values between 0 and 1, with 1 representing the highest attainable standards.

Second, as an alternative proxy for human development we calculate the Non-Income Human Development Index (NIHDI) by subtracting the income effect from the HDI. A country's per capita GDP is correlated with the HDI directly but also indirectly through the impact of income on life expectancy and education. In fact, the correlation coefficient between HDI and per capita GDP for our sample is 0.85 . However, the 
fact that the correlation between these variables is not perfect suggests that factors other than achieved GDP also contribute to human development. Furthermore, some countries are better than others at translating income into human development. Thus, the purpose of the NIHDI is to capture more effectively the fraction of HDI that is not due to GDP.

To compute the NIHDI we estimate the equation:

$$
H D I_{i t}=\chi_{0}+\chi_{1} g\left(G D P_{i t}\right)+\varepsilon_{i t}
$$

Where, $\chi_{0}$ is an intercept term, $\chi_{1}$ is a slope coefficient, $g(G D P)$ is some transformation of per capita income and $\varepsilon$ is an error term. The NIHDI for any given country is simply the absolute value of the estimated value of $\varepsilon_{i t}$ obtained from estimating equation (1.1). In other words, $N I H D I_{i t}=\left|\hat{\varepsilon}_{i t}\right|$. The transformation of income in equation (1.1) accounts for the possibility that the relationship between HDI and per capita income may be non-linear and we use the Box-Cox transformation to allow the data to determine which functional form is more appropriate. This Box-Cox transformation is:

$$
g\left(G D P_{i t}\right)=\frac{G D P_{i t}^{\lambda}-1}{\lambda}
$$

where $\lambda$ is an unknown parameter. We then substitute equation (1.2) into equation (1.1) and obtain the pooled Maximum Likelihood estimates $\hat{\chi}_{0}, \hat{\chi}_{1}, \hat{\lambda}$ and $\hat{\varepsilon}$ for $\chi_{0}, \chi_{1}, \lambda$ and $\varepsilon$ respectively. Results for these estimates are presented in Table 1.1 and indicate that $\lambda$ is statistically significant at the

Table 1.1 Estimates of the parameters of the Box-Cox transformation in equation (1.1) with data for period 2000-2010

\begin{tabular}{lc}
\hline Variable & Pooled Maximum Likelihood Estimates \\
\hline Lambda & $-0.07^{* *}$ \\
& $(0.03)$ \\
Transformed GDP & $0.2^{* * *}$ \\
Chi-squared value for test H0: $\chi_{1}=0$ & 1354 \\
Constant & -0.7 \\
Sigma & 0.04 \\
LR Chi-squared & $1354^{* * *}$ \\
Number of observations & 704 \\
\hline
\end{tabular}

Notes: Standard error between brackets. ***,**,* indicate significance level at 1\%, 5\% and $10 \%$ respectively. 
5 percent level and its point estimation is -0.07 . Moreover, transformed GDP is statistically significant.

To proxy the size of the informal economy, as others before us, we face the challenge of obtaining accurate measurements of the scope of these activities. Current efforts to develop such measurements include indirect estimation (Schneider et al., 2010), labor force statistical profiles (ILO, 2011), and direct estimation measures such as labor force and household surveys (Tickamyer and Wood, 2003). ${ }^{3}$ In this chapter, we use three alternative proxies: necessity-driven entrepreneurship as measured by Global Entrepreneurship Monitor (GEM) data; the proportion of self-employment in the labor force from the LABORSTA database of the International Labor Organization (ILO); and the Shadow Economic Index built by Schneider et al. (2010). While each of these proxies suffers from some shortcomings, they are routinely used to estimate informal activity. More importantly, we believe that the comparative use of all three may have the twofold merit of highlighting different though complementary aspects of informal activity as well as serving as a robustness check.

Our first proxy for the informal sector consists of the percentage of the adult population involved in necessity entrepreneurship (NEC), that is, the percentage of the adult population actively involved in starting a business because of the lack of alternative employment opportunities. NEC data are obtained from the adult population surveys conducted annually by the Global Entrepreneurship Monitor (GEM) project. ${ }^{4}$ Started in 1999, GEM is the largest ongoing data collection effort focusing on entrepreneurs, their motivations, and the characteristics of their businesses. ${ }^{5}$ NEC entrepreneurship consists primarily of self-employed individuals, is significantly higher in low and middle-income countries (Acs and Amorós, 2008; Bosma et al., 2008), and captures most of the informal activities accomplished by survivalist entrepreneurs (Shane, 2009). Ample evidence exists that the majority of necessity based selfemployed individuals operate in the informal sector (Banerjee and Duflo, 2007; De Soto, 1989), especially in Latin America and Africa (Parker, 2004; Shane, 2009). For these reasons, NEC entrepreneurship is a reasonable proxy for the informal sector or, at least, that part of the informal economy that is involved in the creation of micro-enterprises (Naudé et al., 2008).

As a second proxy for the informal sector we use the ratio of selfemployed to total workers from the LABORSTA database of the ILO. Gollin (2008), Maloney (2004), Naudé et al. (2008), and Nichter and Goldmark (2009) all have shown that the vast majority of self-employed individuals are active within micro-enterprises that operate in the informal 
sector. While suffering from clear shortcomings, self-employment is nonetheless a 'popular measure' of informality (Perry et al., 2007, pp. 1-2). In order to make our analysis of self-employment comparable with analysis on GEM data, we only consider data for countries that participated in the GEM project.

Finally, our third proxy for the informal sector is the Shadow Economic Index (SEI) built by Schneider et al. (2010). The index estimates the size of the informal economy in 162 countries for the 1999-2007 period. The SEI uses data on a set of institutional variables that may cause a shadow economy to develop; namely, share of direct taxation, size of government, fiscal freedom, business freedom index, government effectiveness, unemployment rate and Gross Domestic Product (GDP) per capita. In this case, the size of the informal sector is expressed as a percentage of GDP. The strength of SEI data is that, to our knowledge, they are the only available measure built using the same estimation and sampling techniques with the specific purpose of assessing the size of the informal sector in a large number of countries. The main weakness of the SEI data is that they provide only an indirect measure of the size of the informal sector.

In the previous section we argued that changes in a country's development over time depend, at least in part, on informal activity which, in turn, is a function of the country's institutional context. In the short run, institutions can be considered exogenous to the relationship between development and informal activity, that is as an unobserved effect in the panel data analysis. Thus, we use Regulation Quality $(R Q)$ and Economic Freedom $(E F)$ to proxy the institutional environment in each country and as instruments in our models.

The variable $R Q$ comes from the World Bank's Worldwide Governance Indicators which include aggregate and individual governance indicators at the country level (Kaufmann et al., 2009). This variable is related to the capability of the government to formulate and implement programs, policies and regulations that permit and promote private sector development. Within this context, regulation of better quality implies increased incentives to abandon the informal economy. The $E F$ variable, instead, comes from the annual Index of Economic Freedom produced by The Wall Street Journal and The Heritage Foundation. The Index covers 10 freedoms from property rights to entrepreneurship - and tracks economic freedom around the world. In this chapter we use the overall score of the total Economic Freedom Index $(E F)$.

Finally, we include dummy variables for each country in order to capture other country-specific heterogeneity. ${ }^{6}$ Table 1.2 shows the sample size for each variable. 
Table 1.2 Sample size

\begin{tabular}{lccc}
\hline Variable & $\begin{array}{c}\text { Number of countries } \\
(n)\end{array}$ & $\begin{array}{c}\text { Average length of the data } \\
(\text { average } T i)^{*}\end{array}$ & $n \times T i$ \\
\hline HDI & 64 & 11 & 704 \\
SE & 60 & 6.9 & 413 \\
NEC & 85 & 4.8 & 406 \\
SEI & 78 & 7.9 & 622 \\
EF & 82 & 8.4 & 686 \\
RQ & 84 & 9.2 & 777 \\
\hline
\end{tabular}

Note: $* T i=$ average number of years for which we observe that variable for country $i$.

\section{ESTIMATION PROCEDURES AND RESULTS}

\section{Empirical Model and Estimation Strategy}

We test the hypothesis that, given the entrepreneurial nature of the informal sector, a positive relationship exists between the size of the informal sector and a country's economic development. Empirically, we are thus interested in modeling a country's development trend, that is, the changes in its HDI, as a function of the size of that country's informal economy over time. By doing so, we capture the idea that changes in a country's development do not depend on the size of the informal economy in any specific year but on the persistency of that variable over time. In addition, doing so allows us to correct for possible misleading effects of the business cycle. To incorporate trends, we calculate moving averages for all specifications of our model. In general, our model takes the form:

$$
\begin{gathered}
\text { Development index }_{i t}-\text { Development index }_{i t-s}=\alpha_{0}+\alpha_{1} \text { Average size } \\
\text { informal sector } r_{i t}+\alpha_{i}+\varepsilon_{i t}
\end{gathered}
$$

where $\alpha_{0}$ and $\alpha_{1}$ are unknown parameters; parameters $\alpha_{i}$ are countryspecific effects that capture unobserved countries' institutional settings; and $\varepsilon_{i t}$ are random disturbances distributed with 0 mean $\left(E\left[\varepsilon_{i t}\right]=0\right)$.

We use two alternative measures of changes in development. First, we consider the change in HDI over a five-year period for each country. We choose a five-year period to be consistent with the Human Development Index report that calculates the short-term progress of human development as the change in the HDI over that same time period. Second, we 
consider the change in the Non-Income Human Development Index (NIHDI) over a four-year period for each country. The four-year period is chosen instead of a five-year period to avoid losing too many observations.

As discussed earlier, measures for the average size of the informal sector are: (a) each country's five-year moving average of NEC; (b) each country's five-year moving average of SE; and (c) each country's fouryear moving average of SEI. For empirical purposes we relate the moving averages for NEC entrepreneurship and SE to that of the HDI, and the moving average of SEI to that of NIHDI. We do not test for the relationship between changes in HDI and changes in SEI due to collinearity issues since both indexes are a function of GDP per capita. Table 1.3 summarizes the descriptive statistics, whereas Table $1.4 \mathrm{a}$ and Table $1.4 \mathrm{~b}$ provide the full correlation matrices for the five-year HDI trend and moving averages, and for the four-year NIHDI trend and moving averages respectively.

Importantly, the relationship between a country's development and its informal sector may be characterized by two-way causality with resulting endogeneity problems. Although we are not aware of any study that addresses this point explicitly, Van Stel et al. (2005) and Thurik et al. (2008) have provided evidence of two-way causality between entrepreneurial activity and GDP (which is included in the HDI). Thus, the appropriate estimation methods for the parameters of the proposed model depend on whether the average measures of the size of the informal economy are endogenous, as well as on whether there is a correlation between them and the random variable that captures the unobserved institutional context of a country $\left(\alpha_{i}\right)$. If proxies for the informal economy are endogenous we need an estimation approach based on instrumental variables.

An instrument is a variable that does not itself belong in the explanatory equation and is correlated with the endogenous explanatory variables, conditional on the other covariates. More specifically, the instrumental variables must be correlated with the endogenous explanatory variables, informal activity in our case, but cannot be correlated with the error term in the explanatory equation. To address this potential problem, we use the generalized method of moments (GMM) distance statistics ' $\mathrm{C}$ ' test. ${ }^{7}$ GMM estimators are consistent, asymptotically normal and efficient. We performed tests for the endogeneity of the variables used to proxy the informal sector assuming a fixed effect model. This ensured that we test also for the correlation between these variables and the random disturbance.

We implemented that ' $\mathrm{C}$ ' test using country dummies together with moving averages for $E F$ and $R Q$ as instruments. Results indicate that we cannot reject the null hypothesis that the moving average of $N E C, S E$ and $S E I$ are exogenous. Thus, we can be reasonably confident of the consistency of our estimates. 


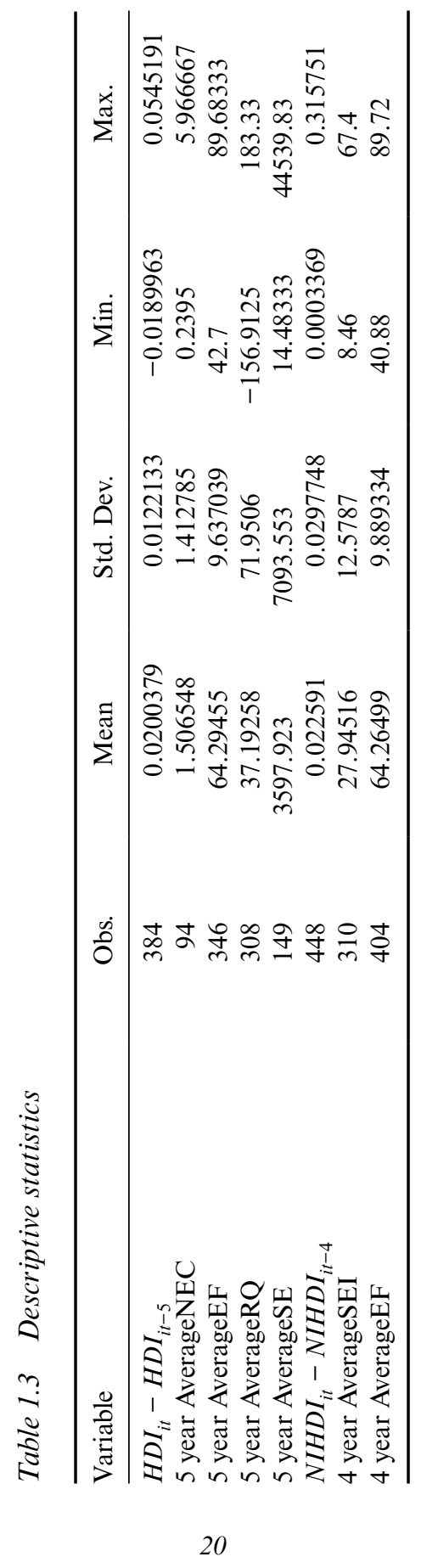




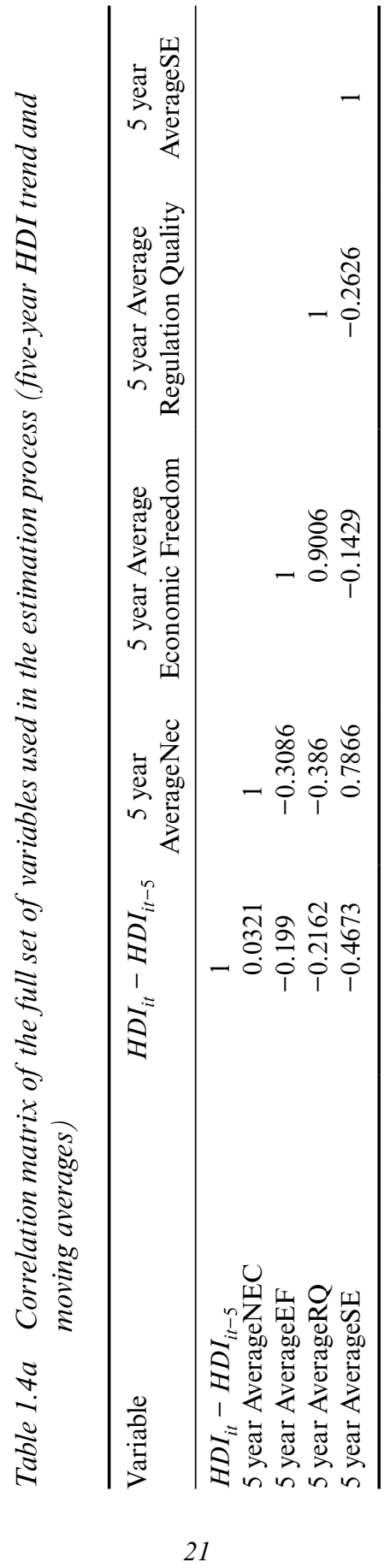


Table 1.4b Correlation matrix of the full set of variables used in the estimation process (four-year NIHDI trend and moving averages)

\begin{tabular}{llcc}
\hline & NIHDI $_{i t}-N I H D I_{i t-4}$ & $\begin{array}{c}\text { 4 year Average } \\
\text { SEI }\end{array}$ & $\begin{array}{c}\text { 4 year Average } \\
\text { Economic Freedom }\end{array}$ \\
\hline NIHDI $_{i t}-N_{\text {NIHDI }}$ & 1 & & \\
4 year AverageSEI & 0.2573 & 1 & \\
4 year AverageEF & 0.0182 & -0.3702 & 1 \\
\hline
\end{tabular}

In addition, we use a Hausman test to assess whether the unobserved institutional context of a country is correlated with the size of its informal sector. The Hausman test indicated that it is not possible to reject the hypothesis that the correlations between them are, in fact, 0 . Thus, it is possible to get consistent and efficient estimates for the parameters of our models using a random effect model or a pooled OLS model. If OLS is used, a panel-corrected standard error and t-statistics must be used for statistical inference. This leads to a panel-robust estimate of the asymptotic variance matrix of the pooled OLS estimator which controls for both serial correlation and heteroskedasticity.

\section{Results}

Given the result of the Hausman test, we chose the estimation procedure providing the most efficient estimates. To measure the effect of the five-year moving average of NEC on the five-year moving average of HDI, estimation efficiency is reached with pooled OLS and by allowing for intragroup correlation and variance heterogeneity for the residuals. Efficiency is also reached in this case with a random effect model allowing for variance heterogeneity in the residuals. Columns 1 and 2 in Table 1.5 show the results of these two estimation procedures. The two methods provide very similar results, suggesting that the latter are robust. Specifically, the results show that increases in the moving average value of NEC are associated with increases in HDI. This provides some support for our hypothesis that the size of the informal sector has a positive effect on countries' development.

In order to gain a better understanding of the impact value of our estimates, we use the estimated coefficients to calculate the elasticity between the two variables. That is, we measure the percentage change in the moving average of HDI resulting from a 1 percent change in the moving average of NEC. Our calculations indicate that such elasticities vary across countries ranging in absolute values from 0.08 (Slovenia) to 1.16 (Brazil) in the 
Table 1.5 Estimates of the models for HDI and NIHDI trend as a function of different measures of the informal economy

\begin{tabular}{|c|c|c|c|c|}
\hline \multirow[t]{2}{*}{ Variable } & \multicolumn{3}{|c|}{5 year HDI trend } & \multirow{2}{*}{$\begin{array}{c}4 \text { year } \\
\text { NIHDI } \\
\text { trend }\end{array}$} \\
\hline & $\begin{array}{l}\text { OLS estimates } \\
\text { with intragroup } \\
\text { correlation and } \\
\text { heterogeneity of } \\
\text { variance of the } \\
\text { residuals. }\end{array}$ & $\begin{array}{l}\text { Random effects } \\
\text { estimates with } \\
\text { heterogeneity of } \\
\text { variance of the } \\
\text { residuals. }\end{array}$ & $\begin{array}{c}\text { OLS estimates } \\
\text { with intragroup } \\
\text { correlation and } \\
\text { heterogeneity of } \\
\text { variance of the } \\
\text { residuals. }\end{array}$ & \\
\hline Constant & $\begin{array}{l}0.01 * * * \\
(0.002)\end{array}$ & $\begin{array}{l}0.007 * * * \\
(0.003)\end{array}$ & $\begin{array}{l}0.02 * * * \\
(0.002)\end{array}$ & $\begin{array}{c}0.007 \\
(0.01)\end{array}$ \\
\hline $\begin{array}{l}5 \text { year moving } \\
\text { average of NEC }\end{array}$ & $\begin{array}{l}0.003^{* *} \\
(0.001)\end{array}$ & $\begin{array}{l}0.002^{* *} \\
(0.001)\end{array}$ & & \\
\hline $\begin{array}{l}5 \text { year moving } \\
\text { average of SE }\end{array}$ & & & $\begin{array}{l}2.67 \mathrm{E}-07 * * \\
(1.26 \mathrm{E}-07)\end{array}$ & \\
\hline $\begin{array}{l}4 \text { year moving } \\
\text { average of SEI }\end{array}$ & & & & $\begin{array}{r}0.0006^{*} \\
(0.0003)\end{array}$ \\
\hline $\begin{array}{l}\text { Number of } \\
\text { countries }\end{array}$ & 24 & 24 & 35 & 63 \\
\hline $\begin{array}{l}\text { Number of } \\
\text { observations }\end{array}$ & 91 & 91 & 124 & 250 \\
\hline $\mathrm{R}$-sq overall & 0.15 & 0.15 & 0.04 & 0.03 \\
\hline F-test & $6.11 * *$ & & $4.49 * *$ & \\
\hline Wald chi ${ }^{2}$ & & $4.85^{* *}$ & & $3.41^{*}$ \\
\hline
\end{tabular}

Notes: $\quad$ Standard deviations are between brackets. ***, ** and * indicate $1 \%, 5 \%$ and $10 \%$ significance level respectively.

OLS model and from 0.05 (Slovenia) up to 0.78 (Brazil) in the random effects model. ${ }^{8}$

To measure the effect of the five-year moving average of SE on the five-year moving average of HDI, estimation efficiency is reached with pooled OLS and allowing for intragroup correlation and variance heterogeneity for the residuals. Column 3 in Table 1.5 shows that increases in the moving average value of $S E$ are associated to increases in HDI. Our calculations also indicate that the elasticity between the HDI's trend and the moving average for $S E$ varies across countries and range in absolute value from 0.0003 (Iceland) to 0.38 (Brazil). ${ }^{9}$ Finally, to measure the effect of the four-year moving average of SEI on the four-year moving average of NIHDI, estimation efficiency is reached with a random effect model. Column 4 in Table 1.5 shows that as SEI increases, a country's NIHDI also 
increases. Our calculations indicate that the elasticity between the NIHDI's trend and the moving average of $S E I$ varies across countries and range in absolute value from 0.14 (Uganda) to 8.4 (Croatia).

We noted that the $\mathrm{R}^{2}$ values for the last models are low (4 percent and 3 percent respectively). This implies that, although both models provide further support for our hypothesis that the informal sector has a positive effect on countries' development, their predictive power is limited. In the context of our argument, however, this is not a problem, especially since the F-tests are significant for all models. In fact, our goal is not to predict changes in human development but, rather, to show that informal activity contributes to explaining human development granted, of course, that the latter depends on a number of additional factors.

\section{CONCLUSION}

Our results support our hypothesis that the size of the informal sector has a positive effect on economic development. The rationale for our argument is that most activities in the informal sector are entrepreneurial and that their unintended macroeconomic consequence leads to the mobilization of otherwise unused resources and, as a result, to improvements in economic development, albeit their effect may not be measurable in immediate changes in per capita GDP. In their famous essay on the economic lives of the poor, for example, Banerjee and Duflo (2007) described the relationship between low levels of economic development and entrepreneurship in the following way: 'All over the world, a substantial fraction of the poor act as entrepreneurs in the sense of raising capital, carrying out investment, and being the full residual claimants for the resulting earnings' (p. 151).

Our results hold true for all three proxies we use to measure informality. Furthermore, differences in country-specific elasticities between measures of informality and economic development suggest that the magnitude of this relationship is significantly mediated by observed and unobserved institutional factors. This is consistent with extant research suggesting that institutions have a strong influence on both entrepreneurial activity (whether necessity or opportunity driven) and economic development (Boettke and Coyne, 2007).

In spite of commendable recent efforts (Schneider et al., 2010), the availability of reliable data on the informal sector remains a major challenge for research in this area and, of course, for this chapter. While stemming from the difficulty to obtain accurate measurements of the size of the informal sector, the use of different measures of informality in our analysis provides robustness checks for our results. Our suggestive evidence supports the 
idea that the informal sector should not be viewed as a negative element in the economy (De Soto, 1989) and that, given the bottom-up nature of the entrepreneurial activities undertaken in the informal sector, informality has a positive effect on economic development (Asea, 1996) by allowing individuals to circumvent the costs of compliance imposed by regulatory constraints (Stigler, 1971). In an environment with sub-optimal institutions and, therefore, high costs of doing business, participating in the informal sector is a rational choice at the individual level and may yield efficient outcomes at the aggregate level.

Entrepreneurial activities may be formal or informal and the decision of an individual to operate in one of these sectors or, sometimes, in both, depends on the opportunity costs of each option which, in turn, depend on the quality of institutions (Baumol, 1990; Boettke and Coyne, 2007). On the one hand, the lack of institutions or the existence of a weak institutional environment increases the costs of operating in the formal sector relative to the informal sector (Djankov et al., 2002). On the other hand, doing business in an informal environment exposes entrepreneurs to possible sanctions and fines, involves non-secure property rights, and makes access to credit and the potential realization of productivity-enhancing investments unlikely (De Soto, 2000).

Efficient institutions are those that minimize transaction costs (North, 1990). In a country with efficient institutions, resources flow to those activities where returns are higher and nascent entrepreneurs are able to allocate their efforts with no resources wasted in deciding whether to operate their business in the formal or informal sector. In other words, in a world with efficient institutions, we should not expect a significant informal sector. In practice, however, many institutional arrangements do not minimize transaction costs. Sometimes they reduce them; in many cases, they simply change the nature of these costs or redistribute them among transaction participants (Baumol, 1990; North, 1990). In this case, the informal sector provides a form of competition for the formal sector and, as a result, allows for the mobilization of otherwise unused resources. The size of the informal sector is also shown to matter and the calculated elasticities shed light as to the sizes of the effects involved.

Our results also have clear implications for policy decisions with respect to the necessity to eliminate the informal sector and the cost associated with such an endeavor. In fact, the resources spent in attempts to eradicate informal activities may be better spent correcting institutional inefficiency. Our results suggest that in countries where an informal sector already exists, its elimination is not necessarily welfare enhancing since formality may come at a significant cost. In general, a useful way to think about the trade-offs between formal and informal activities is to view them as 
complementary. Thus, governments may opt for a posture of benevolent indifference where each entrepreneur can choose whether to operate in the formal or informal sector based on relative returns and transaction costs. In turn, the distribution of entrepreneurs between the formal and informal sectors will influence growth and economic development.

Finally, our work lends itself to an immediate and, we believe, important extension: as suggested by Frey (1989), if a certain amount of informal activity is desirable, it would be interesting to investigate whether an optimal size for the informal sector may be identified. An empirical answer to such a question may be impossible to find but analytical models of the economy may prove fruitful in assessing the optimal trade-off between formal and informal activity in the presence of incongruent institutions.

\section{NOTES}

1. Consistently with existing literature and our operationalization of the variables, our study does not include renegade (Webb et al., 2009) or destructive (Baumol, 1990) activity.

2. For more information see the Human Development Report (UNDP, 2013) and, in particular, its statistical annex.

3. For an interesting survey on approaches used to measure the informal economy see Alderslade et al. (2006).

4. Detailed information on the GEM project can be found at www.gemconsortium.org.

5. See Bosma et al. (2012) for sampling and collection procedures, as well as a detailed description of the data and their statistical properties.

6. Countries included in our study are Algeria, Argentina, Australia, Austria, Belgium, Bolivia, Brazil, Canada, Chile, China, Colombia, Croatia, Czech Republic, Denmark, Dominican Republic, Ecuador, Egypt, Finland, France, Greece, Guatemala, Hong Kong, Hungary, Iceland, India, Indonesia, Iran, Ireland, Israel, Italy, Jamaica, Japan, Jordan, Kazakhstan, Korea, Latvia, Lebanon, Malaysia, Mexico, Morocco, Netherlands, New Zealand, Norway, Panama, Peru, Philippines, Poland, Portugal, Romania, Russia, Saudi Arabia, Slovenia, Spain, Sweden, Switzerland, Tunisia, Turkey, Uganda, United Arab Emirates, United Kingdom, United States, Uruguay, Venezuela.

7. More details about this test can be found in Wooldridge (2002, Section 8.5) and in Baum et al. (2003).

8. Following standard economics, elasticities were calculated as $\mathrm{d}(y) / \mathrm{d}(x)^{*}(y / x)$ using countries' mean values for the trend of HDI and the moving average value of $N E C$.

9. Elasticities were calculated as described in note 8 using estimates for $S E$ instead of $N E C$.

\section{REFERENCES}

Acs, Z.J. and J.E. Amorós (2008), 'Entrepreneurship and competitiveness dynamics in Latin America', Small Business Economics, 31 (3), 305-22.

Alderslade, J., J. Talmage and Y. Freeman (2006), 'Measuring the informal economy: one neighborhood at a time', Discussion Paper, The Brookings Institution Metropolitan Policy Program, Washington, DC. 
Amorós, J.E. and O. Cristi (2011), 'Poverty and entrepreneurship in developing countries', in M. Minniti (ed.), The Dynamics of Entrepreneurship: Evidence from Global Entrepreneurship Monitor Data, Oxford: Oxford University Press, pp. 209-30.

Anokhin, S. and W. Schulze (2009), 'Entrepreneurship, innovation and corruption', Journal of Business Venturing, 24 (5), 465-76.

Asea, P. (1996), 'The informal sector: baby or bath water?', Carnegie-Rochester Conference Series on Public Policy, 45, 163-71.

Banerjee, A.V. and E. Duflo (2007), 'The economic lives of the poor', The Journal of Economic Perspectives, 21 (1), 141-67.

Baum, C.F., M.E. Schaffer and S. Stillman (2003), 'Instrumental variables and GMM: estimation and testing', Stata Journal, 3 (1), 1-31.

Baumol, W.J. (1990), 'Entrepreneurship: productive, unproductive and destructive', The Journal of Political Economy, 98 (5), 893-921.

Baumol, W.J., R.E. Litan and C.J. Schramm (2007), Good Capitalism, Bad Capitalism and the Economics of Growth and Prosperity, New Haven, CT: Yale University Press.

Boettke, P. and C. Coyne (2007), 'Entrepreneurial behavior and institutions', in M. Minniti (ed.), Entrepreneurship: The Engine of Growth, Vol. 1 Perspective Series, Westport, CT: Praeger Press-Greenwood Publishing Group, pp. 119-34.

Bosma, N., K. Jones, E. Autio and J. Levie (2008), Global Entrepreneurship Monitor, 2007 Executive Report, Wellesley, MA and London, UK: Babson College and London Business School.

Bosma, N., A. Coduras, Y. Litovsky and J. Seaman (2012), GEM Manual: Design, Data and Quality Control, Wellesley, MA and London, UK: Babson College and London Business School.

Bowen, H.P. and D. de Clercq (2008), 'Institutional context and the allocation of entrepreneurial effort', Journal of International Business Studies, 39 (1), 747-67.

Bruton, G.D., D. Ahlstrom and K. Obloj (2008), 'Entrepreneurship in emerging economies: where are we today and where should the research go in the future', Entrepreneurship Theory and Practice, 32 (1), 1-14.

De Castro, J., S. Khavul and G. Bruton (2014), 'Shades of grey: how do informal firms navigate between macro and meso institutional environments?', Strategic Entrepreneurship Journal, 8 (1), 75-94.

De Soto, H. (1989), The Other Path: The Invisible Revolution in the Third World, New York: Harper \& Row.

De Soto, H. (2000), The Mystery of Capital, New York: Basic Books.

Dell'Anno, R. (2010), 'Institutions and human development in the Latin American informal economy', Constitutional Political Economy, 21 (3), 207-30.

Djankov, S., R. La Porta, F. Lopez-de-Silanes and A. Shleifer (2002), 'The regulation of entry', Quarterly Journal of Economics, 117 (1), 1-37.

Easterly, W. (2002), The Elusive Quest for Growth: Economists' Adventures and Misadventures in the Tropics, Cambridge, MA: MIT Press.

Frey, B.S. (1989), 'How large (or small) should the underground economy be?', in E.L. Feige (ed.), The Underground Economy: Tax Evasion and Information Distortion, Cambridge: Cambridge University Press, pp. 111-29.

Friedman, E., S. Johnson, D. Kaufmann and P. Zoido-Lobatón (2000), 'Dodging the grabbing hand: the determinants of unofficial activity in 69 countries', Journal of Public Economics, 76 (3), 459-93. 
Gerxhani, K. (2004), 'Informal sector in developed and less developed countries: a literature survey', Public Choice, 120 (3-4), 267-300.

Godfrey, P. (2012), 'Toward a theory of the informal economy', The Academy of Management Annals, 5 (1), 231-77.

Gollin, D. (2008), 'Nobody's business but my own: self-employment and small enterprise in economic development', Journal of Monetary Economics, 55 (2), 219-33.

Gries, T. and W. Naudé (2011), 'Entrepreneurship and human development: a capability approach', Journal of Public Economics, 95 (3-4), 216-24.

International Labor Organization, ILO (2011), 'Statistical update on employment in the informal economy', Geneva: Department of Statistics, ILO, available at: http://laborsta.ilo.org/sti/DATA_FILES/20110610_Informal_Economy.pdf.

Johnson, S., D. Kaufmann and P. Zoido-Lobatón (1998), 'Regulatory discretion and the informal economy', The American Economic Review, 88 (2), 387-92.

Kaufmann, D., A. Kraay and M. Mastruzzi (2009), 'Governance matters VIII: aggregate and individual governance indicators for 1996-2008', World Bank Policy Research Working Paper No. 4978, World Bank, Washington, DC.

LaPorta, R. and A. Shleifer (2008), 'The unofficial economy and economic development', Brookings Papers on Economic Activity, 2, 275-364.

Loayza, N. (1996), 'The economics of the informal sector: a simple model and some evidence from Latin America', Carnegie-Rochester Conference Series on Public Policy, 45, 129-62.

Loayza, N., L. Servén and A.M. Oviedo (2005), 'The impact of regulation on growth and informality: cross-country evidence', World Bank Policy Research Working Paper No. 3623, World Bank, Washington, DC.

Maloney, W. (2004), 'Informality revisited', World Development, 32 (7), 1159-78.

Misturelli, F. and C. Heffernan (2008), 'What is poverty? A diachronic exploration of the discourse on poverty from the 1970s to the 2000s', The European Journal of Development Research, 20 (4), 666-84.

Naudé, W., T. Gries, E. Wood and A. Meintjies (2008), 'Regional determinants of entrepreneurial start-ups in a developing country', Entrepreneurship Regional Development, 20 (2), 111-24.

Nichter, S. and L. Goldmark (2009), 'Small firm growth in developing countries', World Development, 37 (9), 1453-64.

North, D.C. (1990), Institutions, Institutional Change and Economic Performance, Cambridge: Cambridge University Press.

Parker, S.C. (2004), The Economics of Self-employment and Entrepreneurship, New York: Cambridge University Press.

Perry, G. et al. (2007), Informality: Exit and Exclusion, Washington, DC: The International Bank for Reconstruction and Development/The World Bank.

Schneider, F. and D.H. Enste (2000), 'Shadow economies: size, causes, and consequences', Journal of Economic Literature, 38 (1), 77-114.

Schneider, F., A. Buehn and C.E. Montenegro (2010), 'Shadow economies all over the world: new estimates for 162 countries from 1999 to 2007', The World Bank Policy Research Working Papers, WPS5356.

Sen, A. (1999), Development as Freedom, New York: Alfred A. Knopf.

Shane, S. (2009), 'Why encouraging more people to become entrepreneurs is bad public policy', Small Business Economics, 33 (2), 141-9.

Stigler, G.J. (1971), 'The theory of economic regulation', The Bell Journal of Economics and Management Science, 2 (1), 3-21. 
Strategic Entrepreneurship Journal (2014), Special Issue: 'Entrepreneurship and Strategy in the Informal Economy', 8 (1), 1-100.

Thurik, R., M.A. Carree, A. van Stel and D.B. Audretsch (2008), 'Does selfemployment reduce unemployment?', Journal of Business Venturing, 23 (6), 673-86.

Tickamyer, A.R. and T. Wood (2003), 'The social and economic context of informal work', in W.W. Falk, M.D. Schulman and A.R. Tickamyer (eds), Communities of Work: Rural Restructuring in Local and Global Contexts, Athens, OH: Ohio University Press, pp. $394-418$.

Tokman, V. (2007), 'Modernizing the informal sector', UN/DESA Working Paper No. 42.

United Nations Development Program (UNDP) (2013), Human Development Report, New York: United Nations.

Van Stel, A., M. Carree and R. Thurik (2005), 'The effect of entrepreneurial activity on national economic growth', Small Business Economics, 24 (3), 311-21.

Webb, J., G.D. Bruton, L. Tihanyi and D. Ireland (2013), 'Research on entrepreneurship in the informal economy: framing a research agenda', Journal of Business Venturing, 28 (5), 598-614.

Webb, J., L. Tihanyi, D. Ireland and D. Sirmon (2009), 'You say illegal, I say legitimate: entrepreneurship in the informal economy', Academy of Management Review, 34 (3), 492-510.

Wooldridge, J. (2002), Econometric Analysis of Cross Section and Panel Data, Cambridge, MA: The MIT Press.

Yamada, G. (1996), 'Urban informal employment and self-employment in developing countries: theory and evidence', Economic Development and Cultural Change, 44 (2), 289-314. 